\title{
Biogeography and conservation in Southeast Asia: how 2.7 million years of repeated environmental fluctuations affect today's patterns and the future of the remaining refugial-phase biodiversity
}

\author{
David S. Woodruff
}

Received: 1 September 2009/Accepted: 9 January 2010/Published online: 3 February 2010

(C) The Author(s) 2010. This article is published with open access at Springerlink.com

\begin{abstract}
Understanding the historical biogeography of this global biodiversity hotspot is as important to long-term conservation goals as ecology and evolution are to understanding current patterns and processes. Today's geography is, however, misleading and typical of only $\sim 2 \%$ of the last million years; $>90 \%$ of that time the region's land area was $1.5-2.0$ times larger as mean sea levels were $62 \mathrm{~m}$ below today's, climates were cooler, and extensive forests and savanna covered the emerged Sunda plains. The region's land area varied two-fold as sea levels fluctuated up to $\pm 50 \mathrm{~m}$ with each of $\sim 50$ Pleistocene glacial cycles, and forests expanded and contracted with oscillations in land area and seasonality. This dynamic geographic history is relevant to the development of biogeographic regionalism and shows that it is today's forests that are refugial, not those of the Last Glacial Maximum. This history affects how species will adapt or shift their ranges in response to global warming and further decreases in land area (submergence of low-lying coastal areas) during the 21 st century. The alternative is mass species extinction. The biota is also threatened by the continued destruction of forest, destruction of Mekong River flood-pulse based ecosystems, and continued human population growth. Human biogeography will become more important in conservation planning as tens of millions of people who depend on protected area forests, riverine ecosystems, and coastal habitats become environmental refugees. Conservation scientists need to become more involved in regional ecological education, environmental stewardship, and ecosystem-based adaptation to sustain as much as possible of this rich biota and the ecological services it provides.
\end{abstract}

Keywords Climate change $\cdot$ Environmental refugees $\cdot$ Hotspots $\cdot$ Paleogeography · Pleistocene · Rainforest · Refugia - Sea levels · Species ranges · Sundaland · Mekong River

D. S. Woodruff $(\bowtie)$

Division of Biological Sciences, University of California San Diego, 9500 Gilman Drive, La Jolla, CA 92093-0116, USA

e-mail: dwoodruff@ucsd.edu 


$\begin{array}{ll}\text { Abbreviations } \\ \text { ENSO } & \text { El Nino Southern Oscillation } \\ \text { LGM } & \text { Last glacial maximum } \\ \text { Ma/ka } & \text { Million/thousand years ago } \\ \text { Myr/kyr } & \text { Million/thousand years }\end{array}$

\section{Introduction}

Biogeography and conservation are linked inexorably by the relationships between habitat area, primary productivity, earth history, and species richness. This linkage is especially strong in Southeast Asia where the areal extent of the land has repeatedly fluctuated twofold in the last few million years. Today's Southeast Asia, with its peninsulas and thousands of islands, is unusually small and fragmented. For over $90 \%$ of the last two million years forests have covered up to twice the area they do today. Present day geography is therefore highly atypical and it will become even more so as the region loses another 7\% of its land area this century, and more in the next. This short and selective introduction to the biogeography of the region focuses on past, present, and future changes as they affect conservation. Space limitations preclude a comprehensive coverage of the underlying distribution patterns of individual species and readers are referred to the proceedings of several recent conferences for an introduction to the vast literature (Hall and Holloway 1998; Metcalfe et al. 2001; Holloway 2003; Hall et al. 2010; Gower et al. 2010).

Southeast Asia is defined herein as including Myanmar, Xishuangbanna (in southernmost Yunnan, China), Thailand, Laos, Cambodia, Vietnam, Malaysia, Singapore, Brunei, the Philippines, the Andaman and Nicobar Islands (of India), and western parts of Indonesia (including Borneo, Java and Sumatra). Wallace (1876) divided this part of Asia into the Indochinese, Sundaic, and Philippine zoogeographic subregions (Fig. 1). A fourth subregion, the Wallacean, lies to the east and has a largely Australian biota and will therefore receive less attention in this review. The diverse communities within each subregion share a common biogeographic history and many genera and families of plants and animals. A finer scale classification of the biota has been proposed by World Wildlife Fund: dividing the traditional subregions (bioregions) into smaller units called ecoregions, 31 Indochinese, and 28 Sundaic and Philippine ecoregions (Wikramanayake et al. 2002). These ecoregions contain geographically distinct sets of natural communities that share a majority of their species, ecological dynamics and environmental conditions. Major natural vegetation communities include tropical rainforest, tropical seasonal forest, tropical deciduous forest, savanna woodland and grassland, montane forests, mangrove forests, and swamp forests (Corlett 2009a). Using the ecoregion as the "fundamental conservation unit", priorities can be based on each ecoregion's biodiversity distinctiveness index and a quantitative assessment of various threats. The biodiversity distinctiveness index captures measures of endemism, species richness, higher taxonomic uniqueness, and the presence of rare habitats (Wikramanayake et al. 2002).

Southeast Asia covers only $4 \%$ of the earth's land area but is home to $20-25 \%$ of the planet's plant and animal species and is a major global biodiversity hotspot (Myers et al. 2000; Mittermeier et al. 2005; Corlett 2009a). The countries in this region are among the richest in terms of species numbers of plants, mammals, birds and turtles. Indochina hosts $>7,000$ endemic plant species (52\% of the flora); Sundaland is even richer, with $>15,000$ endemic plant species (Brooks et al. 2002). Marine patterns are beyond the scope of this review, but the shallow warm waters of the region harbor $30 \%$ of the world's coral reefs 
Fig. 1 Outline map of Southeast

Asia showing the four

biogeographic subregions

(bioregions or hotspots).

According to some authorities the Indochina and Sundaic bioregions meet on the ThaiMalay peninsula at the KangarPattani Line; others place the transition near the Isthmus of Kra. The Sundaic and Wallacea bioregions meet at Wallace's Line between Borneo and Sulawesi

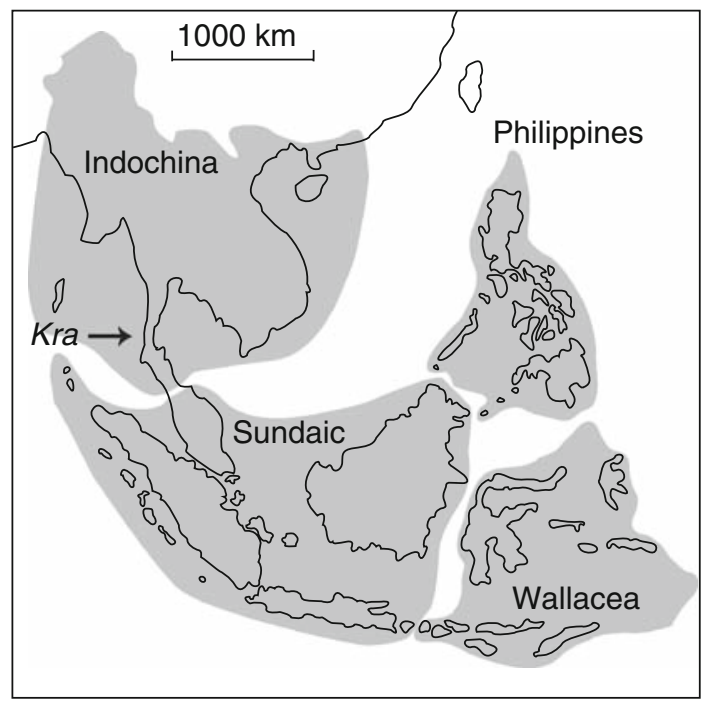

and the greatest diversity of reef associated animals in the world (Spalding et al. 2001). This rich biodiversity is attributed, in part, to the region's geographic position at the transition between the well-differentiated Asian and Australian biogeographic regions, its position in the humid tropics, its history of dramatic changes in land area, and its habitat fragmentation.

Regional freshwater biodiversity is also extraordinary; the region probably has the second richest freshwater fauna in the world in terms of species and endemism (Kottelat 2002; Dudgeon 2005; Dudgeon et al. 2006). The Mekong River alone harbors $\sim 1,100$ species of fish (Rainboth et al. 2010). Indochina has the highest diversity of freshwater turtles in the world (53 species) (Conservation International 2007), Indonesia ranks first for dragonflies and amphibians (Dudgeon 2005). Freshwater communities are included here as many of their conservation problems have biogeographical components stemming from the international courses of rivers and the migratory habits of many fish.

This rich terrestrial and freshwater biota is threatened by human population growth, deforestation and habitat conversion, overexploitation (logging, hunting, fishing, collecting and trade of plants and animals, tissues and parts), invasive species, pollution, and climate change (Sodhi and Brook 2006; Sodhi et al. 2007; Nijman 2010; Peh 2010; Wilcove and Koh 2010). Although a significant area has been designated as protected, both species diversity and ecological services are threatened by habitat destruction proceeding at twice the rate of other humid tropical areas, and by overexploitation at six times the sustainable rate (Sodhi and Brook 2006). These workers estimated that $24-63 \%$ of the region's terrestrial endemic species are threatened with extinction by 2100 . Raven (2009) raised this to $50 \%$ of all species, of which $90 \%$ will still be formally undescribed; an estimate supported by Giam et al. (2010). Freshwater biodiversity is probably experiencing rates of extinction higher than those in the terrestrial biota (Dudgeon et al. 2006) as Asian rivers and wetlands have been seriously degraded by erosion, pollution, overfishing, invasive species, and flow regulation (Sodhi et al. 2007). Humans are the main drivers of this extinction spasm. There are $\sim 500$ million people living in the region at densities twice (Wallacea), three times (Indochina and Sundaland), and six times (Philippines) the world mean of 44 people $/ \mathrm{km}^{2}$ (herein, all demographic data from The Economist 2008). During 
2005-2010 the national populations in the region, with the exception of Thailand, were still growing faster than $1.17 \%$, the world mean annual growth rate. It cannot be overemphasized that this population growth is a main driver of habitat conversion which impacts biodiversity both directly, and indirectly through its contribution to global warming.

The purpose of this introductory review is to show how gradual and continuous environmental fluctuations in the last few million years have shaped today's biogeographic patterns and how regional biodiversity is currently in a spatially compressed or refugial state. The conservation of this rich biodiversity requires the recognition of accelerating rates of anthropogenic change and the predictable redistribution of the growing human population. Human behavior in the next 100-200 years is pivotal to the continued existence of this global biodiversity hotspot.

\section{The biogeographic theater}

Although the basic geographic features, continental outline and mountains have been in place and relatively stable for the last $20 \mathrm{Myr}$, the region's rivers, shorelines, hundreds of continental islands, and climates, have changed dramatically and repeatedly (Corlett 2009a). The earlier geological history of the region, including the assembly of the $>20$ Gondwanan terranes by continental drift, are described elsewhere (Hutchison 1989; Hall 2001, 2002; Metcalfe et al. 2001; Metcalfe 2009). The following brief account of the region's geomorphology, rivers, climates, and vegetation draws on reviews by Woodruff (2003a), Gupta (2005), and Corlett (2009a). Among the main features today are: the IndoMalayan archipelago of 17,000 islands, including two of the largest islands in the world (Borneo, Sumatra), and the Philippines comprising another 7,100 islands. The topography includes the hilly regions of peninsula Malaysia, Sumatra and Borneo, where Mt. Kinabalu rises to 4,101 m, and many volcanically active islands, including Java and Bali. Ancient granite and limestone mountains rising to 2,189 $\mathrm{m}$ form the backbone of the Thai-Malay peninsula and, on the continent proper, there are major hilly tracts in Myanmar, northern Thailand, along the Lao-Vietnamese border (Annamite mountains), and in Cambodia (Cardamon mountains). Other major features include the Chao Phrya river valley that drains into the Gulf of Thailand at Bangkok, and the drier Khorat Plateau of northeast Thailand, which drains east into the current Mekong river.

The region's largest geographic feature lies hidden today below sea level: the plains of the Sunda Shelf. The disappearance of the Sunda plains in the last $14 \mathrm{Kyr}$ presents biogeographers with a highly misleading view of the theater in which today's patterns have developed. The history of this feature and the overall paleogeographic outline of Southeast Asia are closely related to sea levels so the history of the latter must be reviewed at the outset. During the first half of the Tertiary, when sea levels were higher than today's, the Thai-Malay peninsula comprised an island chain with water gaps separating the pre-Tertiary mountains of continental Asia from those in peninsula Malaysia, Sumatra and Borneo. During much of the Miocene (23-5.3 Ma) and Pliocene (5.3-2.6 Ma) conditions were hot $\left(3^{\circ} \mathrm{C}\right.$ warmer), perhumid (wetter than today and covered with rainforest), and sea levels were higher ( $\geq 25 \mathrm{~m}$ relative to today's level) (Haywood et al. 2009; Naish and Wilson 2009). Air temperatures began to decline 3.2 Ma and the Northern Hemisphere continental ice sheets began to form 2.7 Ma. Northern Hemisphere ice sheets began to fluctuate under orbital control, expanding and contracting every 41 ka before $\sim 800 \mathrm{ka}$ and every $100 \mathrm{ka}$ since (Bintanja and van de Wal 2008; Sosdian and Rosenthal 2009) (Fig. 2a). The midPleistocene transition $\sim 800 \mathrm{ka}$ was associated with a cooling of deep ocean water and a 

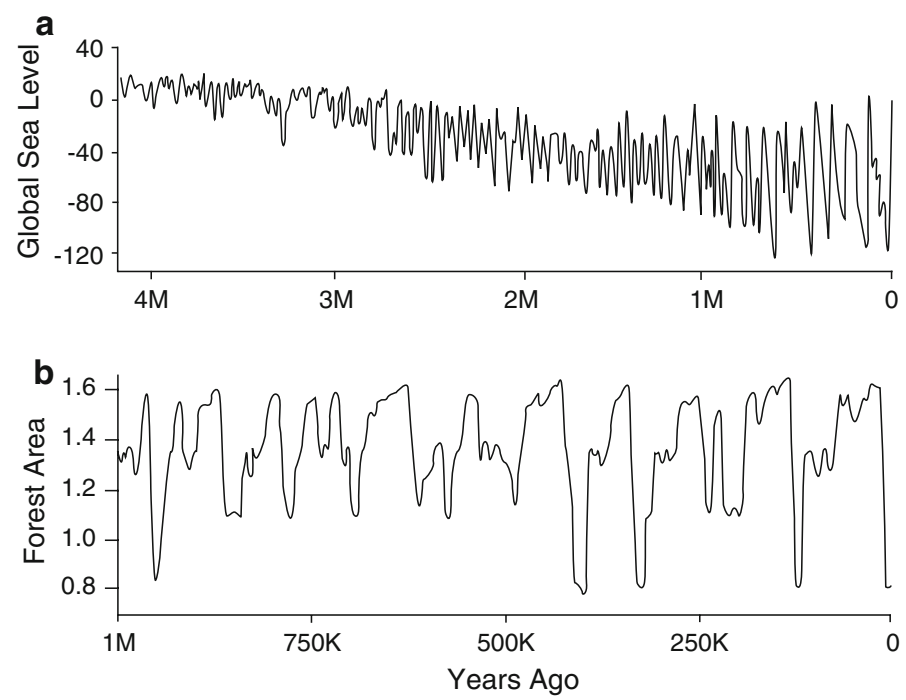

Fig. 2 a Global sea level fluctuations estimated from deep-ocean foraminiferal $\delta^{18} \mathrm{O}$ isotope ratios over the last 4 Ma (data from Lisiecki and Raymo 2005 as transformed by Naish and Wilson 2009 and simplified by hand). b Maximum fluctuations in tropical lowland forest extent in Southeast Asia during the last $1 \mathrm{Ma}$ (after Cannon et al. 2009). This particular curve was produced assuming an equatorial temperature change of $-3^{\circ} \mathrm{C}$ and shows the maximal area of forest in $\mathrm{km}^{2} \times 10^{6}$. More detailed projections for three forest types under this and other paleoclimatic models are provided by Cannon et al. (2009)

substantial thickening of the ice sheets during subsequent glacial phases. During the longer cooler glacial phases of each cycle temperatures, rainfall and sea levels were all lower. During each short interglacial phase sea levels have been within $\sim 10 \mathrm{~m}$ of today's level $(0 \mathrm{~m})$. In contrast, mean sea levels have declined gradually from $-16 \pm 10 \mathrm{~m} \mathrm{2.6} \mathrm{Ma}$, to an average of $-62 \pm 50 \mathrm{~m}$ during the last million years (Figs. $2 \mathrm{a}$ and $3 \mathrm{~b}$ ). The \pm estimates are not uncertainties but the normal glacial-interglacial sea level fluctuations, of which there were $\sim 48$ since $2.4 \mathrm{Ma}$. During periods when sea levels were below $-30 \mathrm{~m}$ extensive coastal plains emerged across the Sunda Shelf and the region's area doubled and provided dry land habitat between continental Asia, Borneo and Bali (Fig. 3a). For example, during the last glacial cycle sea levels fell from $+6 \mathrm{~m}$ at $120 \mathrm{ka}$, to between -124 and $-130 \mathrm{~m}$ during the last glacial maximum (LGM) 19-26 ka, before rising quickly to $+2.5-5.0 \mathrm{~m}$ between 4,850 and 4,450 years ago, and then falling to $0 \mathrm{~m}$ at $3 \mathrm{ka}$ (Horton et al. 2005; Sathiamurthy and Voris 2006; Clark et al. 2009; Hanebuth et al. 2009). During the extreme conditions of the LGM, when the Sunda plains reached their greatest extent, mean annual temperatures on land at sea level were $5-6^{\circ} \mathrm{C}$ lower than today's (Kershaw et al. 2007). The biogeographic significance of the Sunda plains will be discussed further below.

The region is, or was until $\sim 10 \mathrm{ka}$, drained by some of the most productive rivers on earth: the Salween, Chao Phraya (and its antecedent the Siam), Malacca, North Sunda, East Sunda, Mekong, and Red rivers. Throughout most of the Pleistocene the region had many sizable lakes but only the Tonle Sap of Cambodia remains, the others lay on the exposed Sunda Shelf and are now submerged (Sathiamurthy and Voris 2006). There have been changes in the paths of some of the rivers that arise on the Tibetan plateau and flow south through Yunnan (Brookfield 1998; Attwood and Johnston 2001; Meijaard and Groves 2006; 


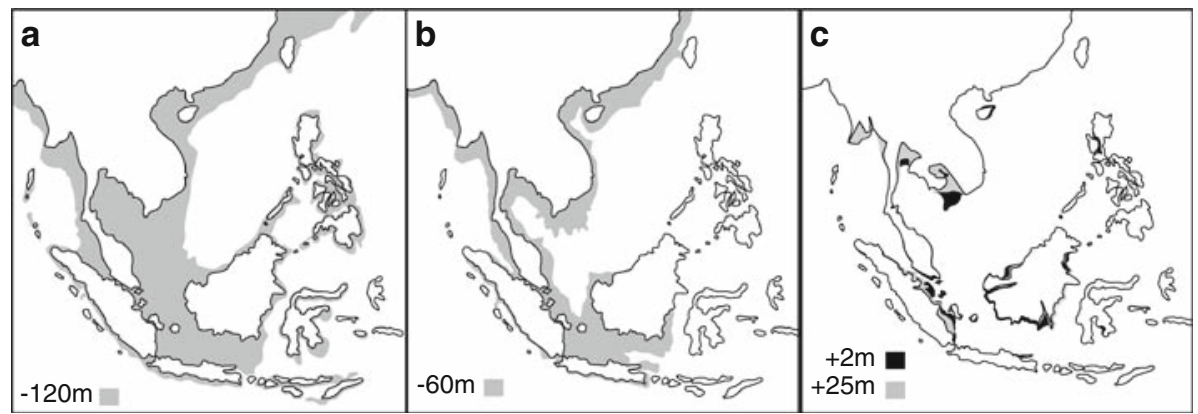

Fig. 3 Outline maps of Southeast Asia when sea levels are at a $120 \mathrm{~m}$ below, b $60 \mathrm{~m}$ below, and c $2 \mathrm{~m}$ above and $25 \mathrm{~m}$ above today's sea level. Sundaland had its greatest areal extent about $20 \mathrm{ka}$ when sea levels fell below $-120 \mathrm{~m}$. The average areal extent of Sundaland in the last million years occurred when sea levels were at $-62 \mathrm{~m}$. Sea levels are expected to rise 1-2 m above today's level in the next 100-300 years. More detailed maps are provided by Sathiamurthy and Voris (2006) who show regional geography at 5-meter increments of sea level change between $-120 \mathrm{~m}$ and $+5 \mathrm{~m}$. Woodruff and Woodruff (2008) provide maps for sea levels at $+2 \mathrm{~m},+25 \mathrm{~m}$ and $+50 \mathrm{~m}$. If all ice sheets on the planet melted sea level would rise to $+50 \mathrm{~m}$, their height $35 \mathrm{Ma}$

Rainboth et al. 2010). The Red river of northern Vietnam, for example, lost its upper reaches [the current Yangtze river] about $75 \mathrm{ka}$. Such changes, the results of river captures and local tectonics, have had a significant impact on the biogeography of freshwater animals. The Salween, Mekong and Yangtze rivers all flow in sutures between adjacent terranes twisted north-south by collision of the Indian and Asian plates. The Mekong (and possibly the Salween by way of today's Ping River) once flowed south to the Gulf of Thailand through what is now the Chao Phrya river valley. They formed a mega-river called the Siam, which delivered enormous quantities of sediment from the Tibetan Plateau to the Sunda Shelf, and carved out the Gulf of Thailand before emptying into the South China Sea. The sequential capture of the upper Mekong by the Yom, Nan and Pasak rivers (all Thai tributaries of today's Chao Phrya) are not well dated but occurred in the last 3 million years. The presentday Mekong river did not develop until the Late Pleistocene; it assumed its present course from Tibet to Vietnam only about 5,000 years ago. The Tonle Sap formed in the last $8 \mathrm{ka}$.

In Southeast Asia temperature variation is less significant in determining the growing season and the natural vegetation than rainfall and its seasonality. The region's characteristic seasonal (monsoonal) climate developed after the rise of the Tibetan plateau $(\sim 30 \mathrm{Ma})$ and the closure of the seaway between the Australian and Asian plates ( $\sim 15 \mathrm{Ma}$ ) and intensified $\sim 10 \mathrm{Ma}$ (Morley 2007; Berger 2009). The frequent interruption of this seasonality by ENSOs became significant 3-5 Mya. Today the region's climates range from perhumid near the equator to markedly seasonal in the interior of Indochina (Chuan 2005; Corlett 2009a). Annual mean rainfall varies from 1,000-2,000 mm over most of continental Southeast Asia, to 2,000-3,000 in the Thai-Malay peninsula, Sumatra and southern Borneo, and $>3,000 \mathrm{~mm}$ in central Borneo and isolated super-wet spots elsewhere. Weck's climatic index (which includes a measure of seasonality based on water availability and temperature) also shows this north-south variation; from 200-300 in the seasonal north to $>1000$ in the perhumid equatorial south. Accordingly, forest productivity increases from $150-250 \mathrm{Mg} \mathrm{C} / \mathrm{ha}$ [million grams of carbon per hectare] in the north to 300-350 Mg C/ha in the south (Brown et al. 2001). 
The summer or southwest monsoon brings heavy rain from the warm Indian Ocean from June through August. In contrast, the typically drier northeast monsoon winds blow in the reverse direction from January through March. Between the two monsoons, or following the summer monsoon if there is only one, there is a hot dry season of 1-7 months duration (December through May is typical). Plant distribution and phenology is associated with rainfall seasonality and variability, and animals in turn tend to track plant productivity (see Brockelman 2010 for a recent discussion of the implications of seasonality at one site). This annual monsoonal pattern has been disrupted by ENSO events every 4-6 years (during in the 20th century) that are associated with drought and increased fire frequency (e.g., 1997-8, 2006-7) (Berger 2009; Taylor 2010). There are also super-droughts, some associated with $\sim 40$ year global drought cycles and others with 10-15 years concordance of ENSO and Indian Ocean dipole cycles.

It is in this setting that Wallace first recognized the four zoogeographic subregions and the major zoogeographic transition between Oriental and Australian regions. That transition, which lies between the Sundaic and Wallacean subregions, is associated with Makassar Strait, which serves as a marine barrier to the dispersal of land animals between Borneo and Sulawesi. This Strait is better known as the location of Wallace's Line and is discussed at great length elsewhere (Whitmore 1987; Hall and Holloway 1998; Metcalfe et al. 2001; Hall et al. 2010; Gower et al. 2010). Plants show a different pattern with a significant transition between Continental Asiatic and Malesian floral regions occurring, not at Wallace's Line, but at a line drawn between Kangar (Malaysia) and Pattani (Thailand) on the peninsula near the Thai-Malay border (van Steenis 1950) (Fig. 1). The Malesian floral region encompasses the peninsula south of the Kangar-Pattani Line and all of the islands of Southeast Asia from Sumatra to the Philippines and New Guinea (Morley 2000; Wikramanayake et al. 2002). The Malesian forests differ from the Indochinese in having far more species and series of ecologically sympatric congeneric species (especially dipterocarps), and the tendency to exhibit synchronous mass [mast] fruiting. To locate the Malesian-Asian transition van Steenis used distribution maps for 1,200 genera of plants; he found that 375 genera of Sundaic plants reach their northern limits, and 200 genera of Indochinese plants reach their southern limits, at the Kangar-Pattani Line at $6-7^{\circ} \mathrm{N}$. This transition is twice the magnitude to that occurring in plants at Wallace's Line.

Wallace (1876) did not recognize the Kangar-Pattani Line but put the boundary between the Indochinese and Sundaic zoogeographic regions at the northern end of the Thai-Malay peninsula at about $14^{\circ} \mathrm{N}$. For many years this transition has been casually associated with the Isthmus of Kra (Fig. 1), which is actually $300 \mathrm{~km}$ further south at $10^{\circ} 30^{\prime} \mathrm{N}$. Hughes et al. (2003) studied the avian Indochinese-Sundaic transition and found a significant turnover in bird species between $11^{\circ} \mathrm{N}$ and $13^{\circ} \mathrm{N}$, just north of the Isthmus of Kra; 152 species, or half the forest-associated species present regionally, have range limits in this area. In many genera, northern species are replaced with southern species with very little range overlap. In mammals, Woodruff and Turner (2009) also traced the transition to the northern third of the peninsula but, instead of a narrow zone of replacement near the Isthmus of Kra, they found (1) an area of the peninsula from $8-14^{\circ} \mathrm{N}$ with $30 \%$ fewer species than expected and (2) Indochinese and Sundaic species range limits clustered just north $\left(14^{\circ} \mathrm{N}\right)$ and south $\left(5^{\circ} \mathrm{N}\right)$ of this species richness anomaly. Elements of this pattern are similar to those found independently by Cattulo et al. (2008). As in the plants, the faunal dissimilarity across the mammal Indochinese-Sundaic transition is greater than that on either side of Wallace's Line (Kreft and Jetz, in review). Comparable analyses of the magnitude and location of the zoogeographic transition in other phyla are still lacking but, as a broad generalization, reptiles, amphibians and butterflies exhibit similar patterns 
(references in Woodruff 2003a, b). The history of the Indochinese-Sundaic transition will be discussed more below.

\section{Biogeographic issues of relevance to conservation}

\section{Documenting biogeographic patterns}

Any discussion of regional patterns must begin by noting the strengths and weaknesses in the underlying distributional database. Its great strengths lie in the richness of the species lists and the fact that observations of many taxa span 200 years. The two great weaknesses remain the geographic gaps in the survey work and the ad hoc nature of the record keeping. Wars, insurgencies and inaccessibility prevented biological exploration of parts of the region for many years and survey work has been a low priority of regional governments. Parnell et al. (2003) provide an excellent quantification of the effects of collecting patterns on our knowledge of Thai plants. The probable extent of our ignorance is indicated by the description of hundreds of new species of vertebrates and plants in both Vietnam and central Borneo since 1992 (Sterling et al. 2006; World Wildlife Fund 2009). Similar surprises can be expected in Myanmar where the northern limits of the Sundaic biota cannot be considered known until the Tenasserim is surveyed.

The other weakness in the regional distributional database is the lack of standardized record keeping at national levels. Although progress is being made (e.g., SAMD 2008; Scholes et al. 2008; GBIF 2009; Webb et al. 2010), occurrence records based on specimens and sightings are typically buried in notebooks or herbarium sheets and rarely in searchable archives. Dated records are important as scientists attempt to document range shifts; e.g. tapir, Sumatran rhinoceros and orangutans were more widely distributed until recently (Meijaard 2003; Tougard and Montuire 2006; Earl of Cranbrook 2009). Some of the impediments to developing regional public databases for conservation managers are discussed by Srikwan et al. (2006) and Webb et al. (2010).

\section{Patterns of distribution}

There are many biogeographic patterns within Southeast Asia including temperatetropical gradients in species richness, a peninsula effect at the tip of the Thai-Malay peninsula, and numerous examples of the species-area effect. The latter are important to conservationists as the rise in sea level (discussed below) will result in more species losses on smaller islands (Okie and Brown 2009). Other patterns of interest include the location of biodiversity hotspots, centers of endemism and refugia. Although defining hotspots as congruent with whole biogeographic subregions (Fig. 1: Indochina, Sundaic, Philippine and Wallacea), as done by Conservation International (2007), may be too broad-scale for some purposes, the identification of smaller areas of endemism or species richness can guide the location of protected areas, e.g., the Mentawi islands with their 17 species of endemic mammals (Corlett 2009a), numerous isolated karst mountains (Clements et al. 2006, 2008), IUCN's Key Biodiversity Areas (Brooks et al. 2008), and BirdLife International's Important Bird Areas (Chan et al. 2004). Understanding the history of today's hotspots is necessary to establish whether they are ancient and geographically fixed, or whether they have moved in response to past climatic change?

Hotspots of freshwater biota are also known: the mid- and lower-Mekong River has probably the second richest fish fauna in the world (Rainboth et al. 2010) and also harbors a 
very diverse mollusc fauna. Unfortunately, both the basic documentation of this fauna and the still confused history of the region's rivers make it difficult to delimit aquatic hotspots. Although terrestrial biotas may be conserved by protecting hotspots (fortress conservation) this approach is less useful for river and wetland biotas whose conservation typically requires watershed level management.

If hotspots capture areas of great species richness today, Pleistocene refugia are thought to have enabled these species to survive environmental challenges in the past. Several workers have argued that during cooler glacial conditions rainforest retreated to the hills of peninsula Malaysia, western Sumatra, the Mentawi Islands, and the center of Borneo, and that during hypothermal periods the rainforest was replaced by savanna woodland or grassland on the emerged Sunda plains and elsewhere (Heaney 1991; Morley 2000, 2007). The extent to which a continuous or broken savanna corridor covered parts of the Sunda Shelf from Indochina to Borneo is controversial as the evidence is mixed and often sitespecific (Kershaw et al. 2001, 2007; Meijaard 2003; Bird et al. 2005; Meijaard and Groves 2006; Wang et al. 2009). Recently, Cannon et al. (2009) have modeling of the changes in distribution of major forest types during the last full 120,000-year glacial cycle and found they actually expanded rather than contracted in their ranges during each hypothermal phase. They modeled the distribution of lowland evergreen rainforest, upland forest $(>1,000 \mathrm{~m})$, and coastal mangrove forest over a large portion of Sundaland and their results, under several different climate scenarios, show that lowland and montane forests were far more extensive during most of the glacial period, with or without the development of a savanna corridor across the region. Modeling the last million years they concluded that it is today's rainforests that are refugial and not those of, for example, the LGM. Southeast Asian forest changes are the opposite of those in better-known temperate regions; rather than shrinking during cooler periods, the lowland evergreen rainforest doubled in area as it spread across the emergent Sunda Shelf (Fig. 2b). Upland forest was 2-3 times more extensive for most of the last $120 \mathrm{kyr}$ than it is during the present interglacial. The distribution of mangrove forest is more complicated: their minimum extent was during the LGM and their greatest extent was when sea levels were between $-40 \mathrm{~m}$ and $-70 \mathrm{~m}$, typical sea levels during most of the last million years. Mangrove forests have moved almost continuously and repeatedly with the shorelines over distances of $>500 \mathrm{~km}$ for most of the last $2 \mathrm{Ma}$. When their model is extended to nearby continental regions it will be most interesting to see how the seasonally dry evergreen forests change their distribution or were transformed into more deciduous forests.

Cannon et al.'s (2009) analysis of vegetation changes coupled with Woodruff and Turner's (2009) contribution regarding multiple sea level oscillations and repeated biotic compression (discussed below) over the last million years present a very different biogeographic picture of Southeast Asia than that envisioned by most earlier workers. The norm for the last few million years involves long cooler periods with slightly reduced rainfall, significantly lower sea levels, and 1.5 to 1.75 times as much land. The exceptional state involves the short warmer interglacials (the last $10 \mathrm{ka}$ for example) with higher sea levels and the fragmentation of the land into islands and peninsulas. Interglacial conditions prevailed for $<10 \%$ of last million years.

Biogeographic regionalism: history as a guide to the future

Understanding of the history of hotspots, refugia and biogeographic transitions is important for making projections about the future evolution and distribution of the biota and its conservation (Willis et al. 2007). The transitions between Sundaland and Wallacea 
(discussed above), between Sundaland and the Philippines (see Heaney 2004), and between Indochina and the Palearctic (Corlett 2009a) are reasonably well known and will not be discussed further here. In contrast, a still unsolved biogeographic puzzle involves the differentiation of the Indochinese and Sundaic biotas without any clear geological or geographic barrier. The position of this transition in forest-associated birds and its possible history near the Isthmus of Kra were discussed by Hughes et al. (2003) and Woodruff (2003a, b). Woodruff's (2003a) hypothesis that the peninsula had been cut by barrier-like marine transgressions during the Neogene was not supported by subsequently revised global sea level curves (Miller et al. 2005; Lisiecki and Raymo 2005; Bintanja and van de Wal 2008; Naish and Wilson 2009) but dramatic sea level fluctuations may well account for today's patterns. Woodruff and Turner (2009) hypothesized that the $\sim 58$ significant episodes of sea level rise (of $>40 \mathrm{~m}$ ) (Fig. 2a) and the flooding of the Sunda Shelf during the brief interglacial periods would have halved the habitat area available and forced the biota back repeatedly into refugia like those they are found in today. They suggested that the repeated 50-70\% reduction in habitat area might account for the observed 30\% reduction in mammal species diversity in the northern and central peninsula, and the observed clusters of species range limits north and south of the area.

The Indochinese-Sundaic transition in plants lies $500 \mathrm{~km}$ south of the Isthmus of Kra on the Kangar-Pattani Line and ecology rather than history has been used to explain its position (Fig. 1). Phytogeographers have hypothesized that this transition is associated with the occurrence of one or more months without rainfall north of the Kangar-Pattani Line (Whitmore 1998). Although maps of Weck's Climatic Index show an abrupt change here (Brown et al. 2001), maps of the number of months with no significant rainfall suggest a more complex picture (see Wells 1999; Woodruff 2003a, b). The climatological underpinning of this ecological hypothesis needs to be verified, and van Steenis' unpublished and lost distribution maps of 1,200 plant genera should now be recreated. If, as it seems likely, some Malesian species occur at least $500 \mathrm{~km}$ further north of the KangarPattani Line, where seasonal evergreen rainforest transitions to mixed moist deciduous forest near the Isthmus of $\mathrm{Kra}$, then the plant transition will need reinterpretation (Woodruff 2003a, b).

Today's geography is highly unusual and recognizable for perhaps only $42 \mathrm{kyr}$ or $2 \%$ of the last 2 Myr. It follows that today's plant and animal species distribution patterns may also be unusual and $<10 \mathrm{kyr}$ old (Woodruff 2003a). For most of the last $2 \mathrm{Myr}$ there was almost continuous dry land access between the continent and the islands of Sumatra, Java and Borneo. Land emerged whenever sea levels fell below $-30 \mathrm{~m}$; land bridges between the continent and today's islands were the norm rather than the exception (Fig. 3b). This makes the position of the biogeographic transitions on today's peninsula even more puzzling in the absence of identifiable barriers to dispersal.

Phylogeographic studies using both ancient and modern DNA should eventually resolve this puzzle. If the Indochinese and Sundaic biotas diverged from one another in refugia north and south of today's transitions it should be possible to find genetic evidence of this history in many extant species. Population genetic models of repeated population expansion and contraction from Plio-Pleistocene refugia lead to predictions regarding the loss of population variability and homogenization of population structure that can be tested in extant populations. Phylogeographic studies of diverse plants and animals in Amazonia and northern temperate regions (regions for which the Pleistocene refugium theory was developed) show, however, that general predictions are hard to make as some species follow habitat shifts and others do not (Hofreiter and Stewart 2009). Such differential species-specific response to the same environmental change makes it difficult but not 
impossible to reconstruct regional paleoecology. Nevertheless, pioneering regional phylogeographic studies of forest and savanna associated species coupled with more and better-dated fossil data are helping resolve this biogeographic puzzle; see for example: Chaimanee (2000), Gorog et al. (2004), Harrison et al. (2006), Tougard and Montuire (2006), de Bruyn and Mather (2007), Quek et al. (2007), Earl of Cranbrook (2009), Esselstyn and Brown (2009).

On-going biogeographic changes and the future evolution of small populations and communities

Corlett (2009a) provides a good general introduction to the expected climate changes in Southeast Asia. Since the mid-1970s tropical rainforests have experienced a significant warming at a mean rate of $0.26^{\circ} \mathrm{C}$ per decade (Malhi and Wright 2005). Climatologists make the following predictions for Southeast Asia before the end of this century: a $2.4-2.7^{\circ} \mathrm{C}$ rise in mean annual temperature $\left(4^{\circ} \mathrm{C}\right.$ in subtropical China), a $7 \%$ increase in wet season rainfall, and a drier dry season (Christensen et al. 2007; Bickford et al. 2010). Sea levels are expected to rise $1-2 \mathrm{~m}$ by 2150 and 2.5-5 m by 2300 (WBGU 2007; Rahmstorf et al. 2007; Woodruff and Woodruff 2008) (Fig. 3c). Unfortunately, such projections are not global end-points but rather the conditions expected when atmospheric $\mathrm{CO}_{2}$ is double its pre-industrial concentration. Temperatures and sea levels, for example, will continue to rise after this point if emissions of greenhouse gases are not reduced and if tundra methane out-gasses as expected. Most projections therefore understate the real endpoint values and threats to biodiversity. In addition, there are significant uncertainties regarding the monsoon's seasonality and intensity, the probably higher frequency of ENSO events, and fire (see Taylor 2010). Even the relatively deterministic relationship between atmospheric temperature, ice cap melting and sea level rise is complicated by local isostacy, geoid shape, and the rates of ice sheet melting. Of greatest concern are so-called ecosystem tipping points beyond which current trends are irrelevant, e.g., the Greenland ice cap could collapse (raising sea levels to $+7 \mathrm{~m}$ ) once a certain partial meltdown has occurred (WBGU 2007).

Conservationists need to know whether and how species will shift their ranges in response to global warming (Pimm 2009). The mid-Pliocene ( $3 \mathrm{Ma}$ ), when global temperatures were on average $3{ }^{\circ} \mathrm{C}$ higher, is especially useful as a model of coming vegetation and biome distribution changes (Bonham et al. 2009; Haywood et al. 2009; Salzmann et al. 2008, 2009). Given that many extant species lived in Southeast Asia during the Pliocene, and have survived multiple glacial/interglacial cycles since then, they will probable be less challenged by temperature than seasonality and the length of the dry season. This suggests that they may have sufficient genetic variability and ecological plasticity to adapt to the expected climatic changes. Reports of such adaptive variation and of shifts in species ranges and phenology illustrate the ability of some species to respond individualistically to significant climate change (Parmesan 2006). The following recent regional examples are informative: (1) Baltzer et al. (2007, 2008) describe current determinants of tree species distributions and the evolution of drought tolerance in trees north and south of the Kangar-Pattani Line; (2) Sheridan (2009) found three frog species that occur in both ever-wet Singapore and seasonal Thailand have adapted to the different environments with changes in clutch size, body size, and the timing of oviposition; (3) Round and Gale (2008) found that the lowland Siamese fireback pheasant Lophura diardi, has increased in abundance at higher elevations over 25 years in central Thailand; (4) Peh (2007) found evidence that other bird species have also extended their upper limits 
along elevation gradients; (5) Chen et al. (2009) found that the average altitudes of individuals of 102 montane geometrid moth species on Mount Kinabalu in Borneo increased by $67 \mathrm{~m}$ between 1965 and 2007; (6) Corlett (2009b) discussed the innate dispersal abilities of trees and other plants and concluded that although altitudinal shifts are feasible as they involve short distances $\left(a 3^{\circ} \mathrm{C}\right.$ increase in mean annual temperature is equivalent to an elevational shift of $\sim 500 \mathrm{~m}$ ), the required latitudinal range shifts, which may require dispersal of $>500 \mathrm{~km}$, and are unlikely to occur naturally in the time available; and (7) Bickford et al. (2010) also discuss herpetological examples but argue that many regional amphibians and some reptiles will soon reach the physiological limits of their adaptability. Wright et al. (2009) make the same point but more generally: tropical species are likely to be particularly sensitive to global warming because they are adapted to limited geographic and seasonal variation in temperature, already live at or near the highest temperatures on Earth before global warming began, and are often isolated from potential cool refugia. They found that, even under a moderate global warming scenario, fully $75 \%$ of the tropical forests present in 2000 will experience mean annual temperatures in 2100 that are greater than the highest mean annual temperature that supports closed-canopy forest today.

Discussions about the future movement of species geographic ranges to adapt to global change require a deeper understanding of the genodynamics of natural population than is currently available. The structure and development of species ranges is therefore of great interest but little research on this subject has been conducted in Southeast Asia. The fact that many regional species have transboundary distributions has impeded research given the extra burdens of obtaining research permits to work in two or more countries. Elsewhere, conservationists are focusing more attention on small populations at the geographic edges of species ranges, as these are the ones relevant to tracking adaptation to change and also the ones at greatest risk of extirpation (Kawecki 2008; Sexton et al. 2009). Unfortunately, opportunities for range expansion are increasingly limited as protected areas and habitat corridors are rarely in the right places; sustaining populations in place is becoming the only option. In such cases it is desirable to know whether the peripheral populations have sufficient inherent genetic variability to justify proposed management efforts. It is not sensible to go to great lengths to save peripheral populations simply because they are rare; it would be better to focus on larger populations that have greater evolutionary potential (Woodruff 2001a; Hoglund 2009). The future evolvability of populations is determined in part by their innate genetic variability and efforts to sustain selected populations or accelerate their natural rates of dispersal by translocation (assisted range shifts) presuppose that conservationists pay more attention to genetic variation than they have in the past. This is especially true in Southeast Asia where sustaining species increasingly involves conserving small populations in recently fragmented patches of forest. The ecological effects of habitat fragmentation are well known (see Sodhi et al. 2007); area effects and edge effects may both lead to population extirpation. Lynam (1997) described a case study involving small mammals isolated on forested islands left when a new reservoir filled in Thailand. Small isolated populations will also suffer genetic erosion, the loss of allelic diversity by chance and by inbreeding, and this too may contribute to their extirpation. Studies in Southeast Asia were the first to demonstrate methods that now enable scientists to monitor genetic variability in free-ranging animals: (1) Woodruff (1990, 2003c) introduced noninvasive genotyping using, for example, hair of gibbons, dung of elephants, and feathers of hornbills to obtain DNA without disturbing animals and (2) Srikwan and Woodruff (2000) introduced a technique sensitive enough to detect and monitor the loss of genetic variation within populations isolated for a few generations in the above mentioned reservoir island situation. These genetic techniques will be especially useful in Southeast 
Asia as tropical species typically have patchy distributions, as genetic erosion is an increasing problem and as interventive population management becomes more necessary. Goossens and Bruford (2009) provide an overview of the use of noninvasive genetic analysis in conservation.

An understanding of the history of the biogeographic transitions on the Thai-Malay peninsula is relevant to predicting the behavior of the extant species involved as they respond to on-going changes in local climates. Will the transitions shift to the north with global warming or with changes in the length and distribution of the dry season? Such shifts involve changes in the range limits of the species involved in the transition and information about past range shifts would inform projections about future ones. Making predictions about the future distributions of individual species is difficult as we do not yet understand how communities of species changed between the long glacial phase (norm) and short interglacial phase (refugial) of each glacial cycle (Webb et al. 2008). Although most species appear to make individualistic responses to climate change a lot depends on their dispersal abilities, niche breadth and ecological plasticity (Parmesan 2006; Hofreiter and Stewart 2009). In contrast, other species clearly show similar responses to change; for example, Okie and Brown (2009) analyzed the disassembly of mammal communities isolated on Sunda Shelf islands in the last 14,000 years, and found that species that occur on small islands tend to be nested subsets of more diverse communities inhabiting larger islands. Other examples involve cases where species are known to be even more tightly coevolved and biogeographically dependent on one another. Corlett (2009b) points out that seed dispersing frugivorous birds and mammals will be critical to the survival of many plant species responding to global warming by distributional shifts. Brockelman (2010) discusses specific plants including rambutans that are dependent on gibbons. Other species play critical roles in overall community function as ecological keystone species. So although many species may be interchangeable (Hubbell 2001), the removal of others from a community can have a disproportionately large ecological impact. Large carnivores, for example, are especially vulnerable in fragmented landscapes and their extirpation can lead to increased numbers of small carnivores (mesopredator release) and, in turn, to the decline of their prey (birds and other small vertebrates) (Crooks and Soulé 1999). The biogeography and ecology of large carnivores therefore merits our attention (Sergio et al. 2008).

In this context it is unfortunate that we do not yet understand the ecological significance of the extinction of the regional Pleistocene megafauna. Humans and their dogs (domesticated elsewhere $\sim 40 \mathrm{ka}$ ) are associated with the extinction or widespread extirpation of $>20$ species of mammals including proboscideans, rhinoceroses, hippopotamus, tapirs, hyaenas, giant pangolin, giant panda, river dolphins, and the giant primates, Pongo and Gigantopithecus. Unfortunately, the events are still too poorly documented to discuss either causes or ecological consequences (Louys 2007; Louys et al. 2007; Corlett 2009a). However, the communities in which the extirpated species lived have not collapsed and for conservationists the real worries are not the losses of individual species but the more farreaching effects of ecosystem collapse. The best defense against such catastrophe in Southeast Asia is to reduce human population growth and the rate of habitat conversion and create the largest possible array of protected areas (Sodhi and Brook 2006; Corlett 2009a; Berry et al. 2010). Reserve size is especially important for terrestrial communities like the montane forests that are expected to shrink in size or disappear as the climate warms. Unfortunately, the reserves that we would recommend for today's conditions are not the same as those we will need after 100 years of projected habitat loss and climate change (Lee and Jetz 2008). 
Human biogeography: growing threats to regional biodiversity and ecosystems

Humans have been part of nature in Southeast Asia for a very long time. Homo erectus walked out of Africa $\sim 1.9$ Mya and spread as far as China, Vietnam, Java and Flores. They lived as small bands of hunter-gatherers who made stone tools. We do not yet know what impact they had on Pleistocene vegetation and megafauna but they used fire for the last $800 \mathrm{ka} . H$. erectus was replaced in the last hundred thousand years by populations of $H$. sapiens that left Africa $\sim 85 \mathrm{ka}$. H. sapiens followed the same coastal route to Southeast Asia, arriving $\sim 75 \mathrm{ka}$ and subsequently spread to China and Australia. There is little physical evidence of this history as sea levels $70-80 \mathrm{ka}$ were $50-60 \mathrm{~m}$ below today's (Fig. 3b) and the traces are now submerged. The genetic evidence, on the other hand, is strong and documents the exodus from Africa, the route taken, the origins of the surviving descendants of the first wave of beachcombers in Southeast Asia, and the current patterns of diverse population distribution and admixture (Oppenheimer 2004; Hill et al. 2006). Beginning at the end of the LGM, $\sim 19 \mathrm{ka}$, the coastal populations would have been pushed slowly inland for 12,000 years as sea levels rose from $-130 \mathrm{~m}$ to $+2-5 \mathrm{~m}$, 4,200 years ago. Corlett (2009a) has reviewed the subsequent ecological impacts of these humans. They began spreading up the river valleys and practiced swidden agriculture at least 5,000 years ago. Rice was domesticated about 4,500 years ago in societies that developed water management for paddy field cultivation. Forest clearing accelerated with the development of great regional civilizations and urban centers in the last 1,500 years. Most of the remaining lowland forest was cleared in the last 100 years for timber and replaced by rubber and tree plantations, and much mangrove forest has been converted into shrimp farms. Wilcove and Koh (2010) argue that the rapid growth in palm oil production in the last 20 years is the region's single greatest threat to biodiversity. Today, only $5-7 \%$ of the original vegetation remains except in Wallacea (15\%) (Conservation International 2007) and an unknown number of species have disappeared.

Humans are the major drivers of habitat alteration, climate change and species endangerment and four aspects of human biogeography will increasingly impact regional biodiversity conservation in the 21 st century. These involve changes in the distribution of populations as a result of the relocation of large numbers of environmental refugees (Myers 2001; Dowie 2009, see also Sodhi et al.'s (2010) discussion of the impact of Indonesian transmigration). The movement of tens of millions of people, even without further population growth, is going to increase the pressures on protected areas and biodiversity.

\section{Rural environmental refugees}

Today nearly half the region's population is urban. In 2007, the urban population ranged between $21-32 \%$ (Cambodia, Laos, Vietnam, Thailand), to $48 \%$ in Indonesia, $67 \%$ in Malaysia and $100 \%$ in Singapore. The migration of poor rural people into the cities is thought to be beneficial in that it is followed by a fall in the birth rate and it reduces pressures on wildlife in remaining forests. However, the emergence of a class of relatively rich consumers in the cities creates a national demand for wood and wildlife products (Nijman 2010). Coupled with these local demands there is now an insatiable international market for the same products. The negative impact of urban migration will probably outweigh the positive, as far as biodiversity is concerned, until this aspect of societal development can be countered by educational and legislative programs. 


\section{Protected area refugees}

A second group of environmental refugees are people who live in forests that have recently been designated as protected areas (Hirsch 1997; Hirsch and Warren 1998; Dowie 2009). Some tribal groups have lived in remote hills for centuries and others have been pushed into the forests fairly recently by more powerful lowland groups. These minorities are significant to conservationists as they now inhabit the last patches of less disturbed forest. Can they continue swidden farming and live sustainably in the forest or should they be forcibly removed? Although the Malaysian Orang Asli recently won subsistence use rights within protected areas, the 2 million members of various hill tribes in Thailand have no such legal standing yet, and are accused of degrading the remaining forests, water catchments, rivers and wildlife. The Thai national debate over forest protection has become polarized with two opposing camps approaching conservation very differently and pejoratively labeling each other as "bananas" or "watermelons" (Watershed 1999; Woodruff 2001b, 2006; Fahn 2003). The "bananas" are often Western-trained government ecologists who recognize the importance of protected areas of forest in wildlife conservation and water quality. They have adopted the Western view that man is apart from nature and therefore humans should be removed from the forest regardless of the fact that hill tribe members are difficult to resettle as they lacked citizenship, land rights and education. The alternate view, held by the "watermelons", is that humans are part of nature; their sustainable use of natural resources should be developed and their societal rights must be strengthened. Such views are likely to be held by academic sociologists and championed by the NGOs, and conform to traditional views that humans are part of nature. "Watermelons" are green (environmentalist) on the outside but pink (politically leftist, a pejorative term in this instance) on the inside. In contrast, "bananas" are yellow (Asian) on the outside but white (holding Western views of nature) on the inside. This debate provides a cautionary lesson for some Western conservation biologists on the difficulty of implementing scientific principles cross-culturally; its resolution will determine how many new refugees are created. Ziegler et al. (2009) provide a critical analysis of the consequences for conservation of the demise of swidden agriculture in the hills.

\section{River-flow dependent environmental refugees}

A third group of people who will become environmental refugees are those currently living along rivers like the Mekong and Salween that are threatened by hydropower dams. Damming these rivers will destroy their natural flood-pulse cycle and threatens to exterminate many of the fish that migrate annually into the tributaries and floodplains to feed and breed. It will also impoverish millions who currently depend on flood-related productivity; the lower Mekong is the largest river fishery in the world (Dudgeon 2005) and 73 million people live in its watershed. The most dramatic case of a predictable ecocatastrophe involves the Tonle Sap. The Tonle Sap (Great Lake of Cambodia) lies in a depression that fills with water when the annual flood in the nearby Mekong river forces the Tonle Sap river to flow backward for 3 months. This floodwater fills the lake, which expands from 250,000 to 1.6 million ha and brings nutrients that support 1.2 million people (another 2.4 million live in the basin), a 200 -species fishery that provides Cambodians with $25 \%$ of their animal protein, an internationally important migratory bird refuge, and a rich agricultural area. The lake also protects the Mekong delta of Vietnam, the rice bowl of Southeast Asia, from inundation by serving as a temporary flood-water reservoir. After the flood crest, the Tonle Sap river reverses itself and the nutrient rich water flows slowly back 
down to the Mekong delta for 6 months. The flood-pulse pattern of regional riparian life is now threatened by the construction in China of a cascade of 8 dams on the mainstream of the upper Mekong. Five dams are now filling including the $292 \mathrm{~m}$-high Xiaowan, the second largest dam on earth after Three Gorges. These dams are 2,000 km and several countries away from their effects on people and biodiversity hotspots. Roberts (2001) termed the expected effects fluvicidal and predicted the Tonle Sap's destruction by 2030. The riparian people who will lose their livelihoods are likely to constitute an increasing threat to the remaining biodiversity as they fish out whatever is left in the river, and if they leave to settle elsewhere (Watershed 2006; Woodruff 2008). In 2009 the Mekong River Commission began formulating a Basin Development Plan with environmental flow allocations to ensure the sustainability of fisheries and aquatic ecosystems for the five downstream riparian countries but China is not a member of the Commission and no mitigation agreement has been sought on behalf of the effected people, biodiversity or ecological services. The impacts of the Chinese dams, and additional mainstream dams planned for Laos, on conservation and human affairs are discussed elsewhere (see the journal Watershed (www.terrafer.org), reports of the UN Development Program (UNDP 2008), and Molle et al. 2009). Needless to say, Principle 1 of the 1992 Rio Declaration on Environment and Development, that States must not cause damage to the environment of other States, has yet to be implemented in regional affairs.

\section{Coastal environmental refugees}

Fourteen million of the 28 million people currently living in the Mekong delta of Vietnam will be displaced by a $2 \mathrm{~m}$ rise in sea level (Warner et al. 2009) (Fig. 3c). Although many will relocate to towns, others will seek livelihoods elsewhere and their displacement away from the low-lying coastal areas will impact the region's protected areas. The effects of climate change on the region's typically low-lying rice growing areas will necessitate the intensification of land use elsewhere or the conversion of remaining forest to agricultural use (Woodruff 2001b). Throughout Southeast Asia many tens of millions of people will be driven out of their present homes by sea level rise and storm surge related flooding unless monumental sea walls are constructed (Woodruff and Woodruff 2008).

New roles for conservation biologists

It is a long time since most humans in Southeast Asia lived in harmony with nature (Woodruff 1992; Fahn 2003). Planning for the future of life in the region (human and other), and the ecological services it provides, requires significant changes in the way people understand their ecological and biogeographic interrelatedness. Biodiversity is a low priority in regional environmental impact assessments and ecological services are still taken for granted by policy makers, developers, and the business sector. Attitudinal problems are exemplified by the Thai government spokesman who, defending the damming of the Mun River, a tributary of the Mekong, said: "it is better for the Thais to use the water as it is only wasted if it flows to Laos". Growing political regionalism still amounts to the exploitation of poorer nations by their more powerful neighbors. International institutions, civil society and private greed have all frustrated attempts to encourage environmental stewardship.

Like it or not, conservation scientists have a responsibility to help change this approach to nature and (1) ensure that full valuations of biodiversity, ecosystems and ecological services are available and considered in the review of development projects (Daily 1997; 
Baimai and Brockelman 1998; Daily and Matson 2008; Daily et al. 2009; Dasgupta 2010; Mooney 2010; Sodhi et al. 2007, 2010) and, more importantly, (2) help educate regional leaders and people who influence the policy making process (Clark 2001). Bierbaum and Zoellick (2009) note that we need more centers of excellence to build capacity across public and private sectors to enable innovative education programs, technologies, market solutions, and management practices. Tomorrow's scholars will have to be trained to be more interdisciplinary if they are to solve complex and interrelated environmental and economic problems in concert with climate change. Putz and Zuidema (2008) are correct in noting that academic ecologists have got to focus more on human habitats and less on protected areas if they are to be effective. The biogeography of humans is therefore critically important to sustaining regional biodiversity and ecological services. Three approaches to conservation need to be on every academic curriculum and in every government and private agency's toolkit. First, the community-based conservation approach has benefitted both people and wildlife in certain situations (Western et al. 1994; Borgerhoff Mulder and Coppolillo 2005). Second, bioneering, the interventionist ecological management of species, communities, and ecosystems in a post-natural world, offers radically different solutions to traditional engineering, which seeks to control nature (Woodruff 2001a; Ausubel and Harpignies 2004). Third, ecosystem-based adaptation deserves wide attention as it incorporates the other two approaches (Bierbaum and Zoellick 2009). Ecosystem-based adaptation aims to reduce the vulnerability of people to climate change through the conservation, restoration, and management of ecosystems (World Bank 2009). Human adaptation goals can often be achieved through better management of ecosystems rather than through physical and engineering interventions. For example, mangrove restoration will protect shoreline habitat more effectively from storm surges than sea walls; and the mangroves also sequester carbon and enhance local fishing. Forest restoration is a more effective than agroforestry in watershed protection, builds on local knowledge, and benefits both biodiversity and local communities. Bioneering and ecosystem-based adaptation are both based on the underlying ecological and evolutionary processes and our future ultimately depends on these more than the technological fixes we have enjoyed in the past. It is unfortunate that adaptation and the cooperative behavior it requires are often frustrated by societal institutions that are more interested in selfpreservation and civic stability than intergenerational well-being (May 2010).

Biogeography provides a longer-term view of past biotic change, the product of ecology and evolution in this ever-changing geographic theater, and provides a basis for informed projections about the future. Given the refugial nature of the current Southeast Asian biota, and the predictable trends of the ongoing environmental changes, it is clear that biodiversity and humans together face ominous threats. The window for limiting temperature increases to a tolerable range is closing fast and, although many of the drivers of change lie outside this region, much can be achieved locally by thoughtful mitigation. Working together, biogeographers and conservationists must act as if their efforts in the next 20 years will affect the quality of life in this region for at least a thousand years.

Acknowledgements I thank Navjot Sodhi and Lian Pin Koh for the opportunity of participating in the symposium and the University of California Academic Senate for partial travel support. Two anonymous reviewers provided useful criticisms of the manuscript and Katherine E. LeVan prepared the figures. I am also indebted to Robert Inger who sent me a copy of his seminal monograph on the zoogeography of the Philippines in 1957 when I was 14 years old; it has proven most inspirational. 
Open Access This article is distributed under the terms of the Creative Commons Attribution Noncommercial License which permits any noncommercial use, distribution, and reproduction in any medium, provided the original author(s) and source are credited.

\section{References}

Attwood SW, Johnston DA (2001) Nucleotide sequence differences reveal genetic variation in Neotricula aperta (Gastropoda: Pomatiopsidae), the snail host of schistosomiasis in the lower Mekong basin. Biol J Linn Soc 73:23-41

Ausubel K, Harpignies JP (eds) (2004) Nature's operating instructions: the true biotechnologies. The Bioneers Series. Sierra Club Books, San Francisco

Baimai V, Brockelman WY (1998) Biodiversity research and training program in Thailand. Pure Appl Chem 70:2073-2078

Baltzer JL, Davies SJ, Noor NSM, Kassim AR, LaFrankie JV (2007) Geographical distributions in tropical trees: Can geographical range predict performance and habitat association in co-occurring tree species? J Biogeogr 34:1916-1926

Baltzer JL, Davies SJ, Bunyavejchewin S, Noor NSM (2008) The role of desiccation tolerance in determining tree species distributions along the Malay-Thai Peninsula. Functional Ecol 22:221-231

Berger WH (2009) Ocean. University of California Press, Berkeley

Berry NJ, Phillips OL, Lewis SL, Hill JK, Edwards DP, Tawatao NB, Ahmad N, Magintan D, Khen CV, Maryati M, Ong RC, Hamer KC (2010) The high value of logged tropical forests: lessons from northern Borneo. Biodivers Conserv. doi:10.1007/s10531-010-9779-z

Bickford D, Howard SD, Ng DJJ, Sheridan JA (2010) Impacts of climate change on the amphibians and reptiles of Southeast Asia. Biodivers Conserv. doi:10.1007/s10531-010-9782-4

Bierbaum RM, Zoellick RB (2009) Development and climate change. Science 326:771

Bintanja R, van de Wal RSW (2008) North American ice-sheet dynamics and the onset of 100,000-year glacial cycles. Nature 454:869-872

Bird MI, Taylor D, Hunt C (2005) Environments of insular Southeast Asia during the last glacial period: A savanna corridor in Sundaland? Quaternary Sci Rev 24:2228-2242

Bonham SG, Haywood AM, Lunt DJ, Collins M, Salzmann U (2009) El Nino-Southern Oscillation, Pliocene climate and equifinality. Philos Trans R Soc A 367:127-156

Borgerhoff Mulder M, Coppolillo P (2005) Conservation: linking ecology, economics and culture. Princeton University Press, Princeton

Brockelman WY (2010) Rainfall patterns and unpredictable fruit production in seasonally dry evergreen forest, and their effects on gibbons. In: McShea WJ, Davies S, Phumpakphan N (eds) The unique ecology and conservation of tropical dry forests in Asia. Smithsonian Institution Press, Washington (in press)

Brookfield ME (1998) The evolution of the great river systems of southern Asia during the Cenozoic IndiaAsia collision: rivers draining southwards. Geomorphology 22:285-312

Brooks TM, Mittermeier RA, Mittermeier CG, da Fonseca GAB, Rylands AB, Konstant WR, Flick P, Pilgrim J, Oldfield S, Magin G, Hiltin-Taylor C (2002) Habitat loss and extinction in the hotspots of biodiversity. Conserv Biol 16:909-923

Brooks TM, De Silva N, Duya MV, Foster M, Knox D, Langhammer P, William MR, Tabaranza B (2008) Delineating key biodiversity areas as targets for protecting areas. In: Sodhi NS, Acciaioli G, Erb M, Tan AK (eds) Biodiversity and human livelihoods in protected areas: case studies from the Malay archipelago. Cambridge University Press, Cambridge, pp 20-35

Brown S, Iverson LR, Prasad A (2001) Geographical distribution of biomass carbon in tropical Southeast Asian forests: a database. ORNL/CDIAC-119, NDP-068. US Department of Energy, Oak Ridge National Laboratory, Oak Ridge, Tennessee, p 75

Cannon CH, Morley RJ, Bush ABG (2009) The current refugial rainforests of Sundaland are unrepresentative of their biogeographic past and highly vulnerable to disturbance. Proc Natl Acad Sci USA 106:11188-11193; See Supplemental Information for movies of the simulated changes in vegetation over the last full glacial cycle

Cattulo G, Masia M, Falcucci A, Maioranob L, Rondininib C, Boitani L (2008) A gap analysis of Southeast Asian mammals based on habitat suitability models. Biol Conserv 141:2730-2744

Chaimanee Y (2000) Occurrence of Hadromys humei (Rodentia: Muridae) during the Pleistocene in Thailand. J Mammal 8:659-665

Chan S, Crosby MJ, Islam MZ, Tordoff AW (2004) Important bird areas in Asia. BirdLife International, Cambridge 
Chen IC, Shiu HJ, Benedick S, Holloway JD, Cheye VK, Barlow HS, Hill JK, Thomas CD (2009) Elevation increases in moth assemblages over 42 years on a tropical mountain. Proc Natl Acad Sci USA 106:1479-1483

Christensen JH et al (2007) Regional climate projections. In: Solomon S et al (eds) Climate change 2007: the physical science basis. Contrib Working Group I, 4th Assessment report, Intergovernmental Panel on Climate Change. Cambridge University Press, Cambridge, pp 847-940

Chuan GK (2005) The climate of Southeast Asia. In: Gupta A (ed) The physical geography of Southeast Asia. Oxford University Press, Oxford, pp 80-93

Clark TW (2001) Developing policy-oriented curricula for conservation biology: professional and leadership education in the public interest. Conserv Biol 15:31-39

Clark PU, Dyke AS, Shakum JD, Carlson AE, Clark J, Wohlfarth B, Mitrovica JX, Hostetler SW, McCabe AM (2009) The last glacial maximum. Science 325:710-714

Clements R, Sodhi NS, Schiilthuizen M, Ng PKL (2006) Limestone karsts of Southeast Asia: imperiled arks of biodiversity. Bioscience 56:733-742

Clements R, Ng PKL, Lu XX, Ambu S, Schilthuizen M, Bradshaw CJA (2008) Using biogeographical patterns of endemic land snails to improve conservation planning for limestone karsts. Biol Conserv 141:2751-2764

Conservation International (2007) Biodiversity hotspots: http://www.biodiversityhotspots.org/

Corlett RT (2009a) The ecology of tropical East Asia. Oxford University Press, Oxford

Corlett RT (2009b) Seed dispersal distances and plant migration potential in tropical East Asia. Biotropica 41:592-598

Cranbrook, Earl of (2009) Late quaternary turnover of mammals in Borneo: the zooarchaeological record. Biodivers Conserv. doi:10.1007/s10531-009-9686-3

Crooks KR, Soulé ME (1999) Mesopredator release and avifaunal extinctions in a fragmented system. Nature 400:563-566

Daily GC (ed) (1997) Nature's services: societal dependence on natural ecosystems. Island Press, Washington, DC

Daily GC, Matson PA (2008) Ecosystem services: from theory to implementation. Proc Natl Acad Sci USA 105:9455-9456

Daily GC, Polasky S, Goldstein J, Kareiva PM, Mooney HA, Pejchar L, Ricketts TH, Salzman J, Shallenberger R (2009) Ecosystem services in decision making: time to deliver. Frontiers Ecol Environ 7:21-28

Dasgupta P (2010) Nature's role in sustaining economic development. Philos Trans R Soc B 365:5-11

De Bruyn M, Mather PB (2007) Molecular signatures of Pleistocene sea-level changes that affected connectivity among freshwater shrimp in Indo-Australian waters. Mol Evol 16:4295-4307

Dowie M (2009) Conservation refugees: the hundred-year conflict between global conservation and native peoples. MIT Press, Cambridge

Dudgeon D (2005) River rehabilitation for conservation of fish biodiversity in monsoonal Asia. Ecol Soc 10(2):15. http://www.ecologyandsociety.org/vol10/iss2/art15/

Dudgeon D, Arthington AH, Gessner MO, Kawabata Z, Knowler D, Lévêque C, Naiman RJ, Prieur-Richard A-H, Soto D, Stiassny MLJ, Sullivan CA (2006) Freshwater biodiversity: importance, threats, status and conservation challenges. Biol Rev 81:163-182

Economist, The (2008) Pocket world in figures 2008. The Economist, London

Esselstyn JA, Brown RM (2009) The role of repeated sea-level fluctuations in the generation of shrew (Soricidae: Crocidura) diversity in the Philippine Archipelago. Mol Phylogenet Evol 53:171-181

Fahn JD (2003) Land on fire. The environmental consequences of the Southeast Asian boom. Westview Press, Boulder, CO

GBIF (Global Biodiversity Information Facility) (2009) University of Copenhagen, Denmark (viewed August 15). http://www.gbif.org/

Giam X, Ng TH, Yap VB, Tan HTW (2010) The extent of undiscovered species in Southeast Asia. Biodivers Conserv. doi:10.1007/s10531-010-9792-2

Goossens B, Bruford MW (2009) Non-invasive genetic analysis in conservation. In: Bertorelle G, Bruford MW, Hauffe HC, Rizzoli A, Vernisi C (eds) Population genetics for animal conservation. Cambridge University Press, Cambridge, pp 167-201

Gorog AJ, Sinaga MH, Engstrom MD (2004) Vicariance or dispersal? Historical biogeography of three Sunda shelf murine rodents (Maxomys surifer, Leopoldamys sabanus and Maxomys whiteheadi). Biol J Linn Soc 81:91-109

Gower D, Johnson K, Richardson J, Rosen B, Rüber L, Williams S (eds) (2010) Biological papers from conference, Southeast Asian gateway evolution, held at Royal Holloway College, London, 14-18 September 2009. Systematics Association (in preparation). Program at http://sage2009.rhul.ac.uk/ index.html 
Gupta A (ed) (2005) The physical geography of Southeast Asia. Oxford University Press, Oxford

Hall R (2001) Cenozoic reconstructions of SE Asia and the SW Pacific: changing patterns of land and sea. In: Metcalfe I, Smith JMB, Morwood M, Davidson I (eds) Faunal and floral migrations and evolution in SE Asia-Australasia. Balkema, Lisse, pp 35-56

Hall R (2002) Cenozoic geological and plate tectonic evolution of SE Asia and the SW Pacific: computerbased reconstructions and animations. J Asian Earth Sci 20:353-434

Hall R, Holloway JD (eds) (1998) Biogeography and geological evolution of Southeast Asia. Backhuys, Leiden. Also available at http://www.gl.rhul.ac.uk/seasia/Publications/books/Biogeography/PDFs_/ pdfs_html

Hall R, Cottam M, Wilson M (eds) (2010) The SE Asian gateway: history and tectonics of Australia-Asia collision. Geological Soc London Special Pubs (in preparation)

Hanebuth TJJ, Stattegger K, Bojanowski A (2009) Termination of the last glacial maximum sea-level lowstand: the Sunda-Shelf data revisited. Global Planet Change 66:76-84

Harrison T, Krigbaum J, Manser J (2006) Primate biogeography and ecology on the Sunda Shelf islands: a paleontological and zooarchaeological perspective. In: Lehman SM, Fleagle JG (eds) Primate biogeography. Springer, New York, pp 331-372

Haywood AM, Dowsett HJ, Valdes PJ, Lunt DJ, Francis JE, Sellwood BW (2009) Introduction. Pliocene climate, processes and problems. Philos Trans R Soc A 367:3-17

Heaney LR (1991) A synopsis of climatic and vegetational change in Southeast Asia. Climatic Change 19:53-61

Heaney LR (2004) Conservation biogeography in oceanic archipelagoes. In: Lomolino MV, Heaney LR (eds) Frontiers of biogeography. Sinauer, Sunderland, MA, pp 345-360

Hill C, Soares P, Mormina M, Macaulay V, Meehan W, Blackburn J, Clarke D, Raja JM, Ismail P, Bulbeck D, Oppenheimer S, Richards M (2006) Phylogeography and ethnogenesis of aboriginal southeast Asians. Mol Biol Evol 23:2480-2491

Hirsch P (ed) (1997) Seeing forests for trees: environment and environmentalism in Thailand. Silkworm Books, Chiang Mai and University of Washington Press, Seattle, p 277

Hirsch P, Warren C (eds) (1998) The politics of environment in Southeast Asia: resources and resistance. Routledge, New York

Hofreiter M, Stewart J (2009) Ecological change, range fluctuations and population dynamics during the Pleistocene. Curr Biol 19:R584-R594

Hoglund J (2009) Evolutionary conservation genetics. Oxford University Press, Oxford

Holloway JD (2003) An addiction to Southeast Asian biogeography. Introduction to a collection of papers originated in the conference, Biogeography of Southeast Asia-organisms and orogenesis, held in The Netherlands on 4-9 June 2000. J Biogeogr 30:161-163

Horton BP, Gibbard PL, Milne GM, Morley RJ, Purintavaragul C, Stargardt JM (2005) Holocene sea levels and palaeoenvironments, Malay-Thai Peninsula, Southeast Asia. Holocene 15:1199-1213

Hubbell SP (2001) The unified neutral theory of biodiversity and biogeography. Princeton University Press, Princeton

Hughes JB, Round PD, Woodruff DS (2003) The Indochinese-Sundaic faunal transition at the Isthmus of Kra: an analysis of resident forest bird species distributions. J Biogeogr 30:569-580

Hutchison CS (1989) Geological evolution of south-east Asia. Clarendon, Oxford

Kawecki TJ (2008) Adaptations to marginal habitats. Annu Rev Ecol Evol Syst 39:321-342

Kershaw AP, Penny D, van der Kaars S, Anshari G, Thamotherampilai A (2001) Vegetation and climate in lowland southeast Asia at the last glacial maximum. In: Metcalfe I, Smith JMB, Morwood M, Davidson I (eds) Faunal and floral migrations and evolution in SE Asia-Australasia. Balkema, Lisse, pp 227-236

Kershaw AP, van der Kaars S, Flenley JR (2007) The Quaternary history of far eastern rainforests. In: Bush MB, Flenley JR (eds) Tropical rainforest responses to climate change. Springer, Berlin, pp 77-115

Kottelat M (2002) Aquatic systems: neglected biodiversity. In: Wikramanayake E et al (eds) Terrestrial ecoregions of the Indo-Pacific. Island Press, Washington, pp 30-35

Lee TM, Jetz W (2008) Future battlegrounds for conservation under global change. Proc R Soc B 275:12611270

Lisiecki LE, Raymo ME (2005) A Pliocene-Pleistocene stack of 57 globally distributed benthic $\delta^{18} \mathrm{O}$ records. Paleoceanography 20:Article no. PA1003. doi:10.1029/2004PA001071

Louys J (2007) Limited effect of the Quaternary's largest super-eruption (Toba) on land mammals from Southeast Asia. Quat Sci Rev 26:3108-3117

Louys J, Curnoe D, Tong H (2007) Characteristics of Pleistocene megafauna extinctions in Southeast Asia. Palaeogeogr Palaeoclimatol Palaeoecol 243:152-173 
Lynam AJ (1997) Rapid decline of small mammal diversity in monsoon evergreen forest fragments in Thailand. In: Laurance WF, Bierregaard RO (eds) Tropical forest remnants. Chicago University Press, Chicago, pp 222-240

Malhi Y, Wright J (2005) Late twentieth-century patterns and trends in the climate of tropical forest regions. In: Malhi Y, Phillips O (eds) Tropical forests and global atmospheric change. Oxford University Press, Oxford, pp 3-16

May RM (2010) Ecological science and tomorrow's world. Philos Trans R Soc B 365:41-47

Meijaard E (2003) Mammals of south-east Asian islands and their Late Pleistocene environments. J Biogeogr 30:1245-1257

Meijaard E, Groves CP (2006) The geography of mammals and rivers in mainland Southeast Asia. In: Lehman SM, Fleagle JG (eds) Primate biogeography. Springer, New York, pp 305-329

Metcalfe I (2009) Late Palaeozoic and Mesozoic tectonic and palaeogeographic evolution of SE Asia. In: Buffetaut E, Cuny G, Le Loeuff J, Suteethorn V (eds) Late Palaeozoic and Mesozoic ecosystems in SE Asia. Geological Soc London Special Pubs vol 315, pp 7-22

Metcalfe I, Smith JMB, Morwood M, Davidson I (eds) (2001) Faunal and floral migrations and evolution in SE Asia-Australasia. Balkema, Lisse

Miller KG, Kominz MA, Browning JV, Wright JD, Mountain GS, Katz ME, Sugarman PJ, Cramer BS, Christie-Blick N, Pekar SF (2005) The Phanerozoic record of global sea-level change. Science 310:1293-1298

Mittermeier RA, Gil PR, Hoffman M, Pilgrim J, Brooks T, Mittermeier CG, Lamoreux J, da Fonseca GAB (2005) Hotspots revisited: earth's biologically richest and most endangered terrestrial ecoregions. Conservation International, Washington

Molle F, Foran T, Kakonen M (eds) (2009) Contested waterscapes in the Mekong region: hydropower, livelihoods and governance. Earthscan, London

Mooney HA (2010) The ecosystem-service chain and the biological diversity crisis. Philos Trans R Soc B 365:31-39

Morley RJ (2000) Origin and evolution of tropical rain forests. Wiley, New York

Morley RJ (2007) Cretaceous and Tertiary climate change and the past distribution of megathermal rainforests. In: Bush MB, Flenley JR (eds) Tropical rainforest responses to climate change. Springer, Berlin, pp 1-31

Myers N (2001) Environmental refugees: a growing phenomenon of the 21 st century. Philos Trans R Soc B 357:609-613

Myers N, Mittermeier RA, Mittermeier CG, Da Fonseca GAB, Kent J (2000) Biodiversity hotspots for conservation priorities. Nature 403:853-858

Naish TR, Wilson GS (2009) Constraints on the amplitude of mid-Pliocene (3.6-2.4 Ma) eustatic sea-level fluctuations from the New Zealand shallow-marine sediment record. Philos Trans R Soc A 367: $169-187$

Nijman V (2010) An overview of international wildlife trade from Southeast Asia. Biodivers Conserv. doi:10.1007/s10531-009-9758-4

Okie JG, Brown JH (2009) Niches, body sizes, and the disassembly of mammal communities on the Sunda Shelf islands. Proc Natl Acad Sci USA 106(suppl 2):19679-19684

Oppenheimer S (2004) The real Eve. Carroll and Graf, New York

Parmesan C (2006) Ecological and evolutionary responses to recent climate change. Annu Rev Ecol Evol Syst 37:637-669

Parnell JAN, Simpson DA, Moat J, Kirkup DW, Chantaranothai P, Boyce PC, Bygrave P, Dransfield S, Jebb MHP, Macklin J, Meade C, Middleton DJ, Muasya AM, Prajaksood A, Pendry CA, Pooma R, Suddee S, Wilkin P (2003) Plant collecting spread and densities: their potential impact on biogeographical studies in Thailand. J Biogeogr 30:193-209

Peh KSH (2007) Potential effects of climate change on elevational distributions of tropical birds in Southeast Asia. Condor 109:437-441

Peh KSH (2010) Invasive species in Southeast Asia: the knowledge so far. Biodivers Conserv (this volume). doi:10.1007/s10531-009-9755-7

Pimm SL (2009) Climate disruption and biodiversity. Curr Biol 19:595-601

Putz FE, Zuidema PA (2008) Contributions of ecologists to tropical forest conservation. In: Carson WP, Schnitzen SA (eds) Tropical forest community ecology. Blackwell, Oxford, pp 474-489

Quek SP, Davies SJ, Ashton PS, Itino T, Pierce NE (2007) The geography of diversification in mutualistic ants: a gene's-eye view into the Neogene history of Sundaland rain forests. Mol Ecol 16:2045-2062

Rahmstorf S, Cazenave A, Church JA, Hansen JE, Keeling RF, Parker DE, Somerville RCJ (2007) Recent climate observations compared to projections. Science 316:709 
Rainboth WJ, Vidthayanon Chavalit, Mai DY (2010) Fishes of the greater Mekong ecosystem: species list and photographic atlas. Misc Publ Mus Zool Univ Michigan (in review)

Raven PH (2009) How many species will survive the 21st century. Plenary lecture, Intl Congr Conserv Biol, Beijing, abstracts, p 53

Roberts TR (2001) Killing the Mekong: China's fluvicidal hydropower-cum-navigation development scheme. Nat Hist Bull Siam Soc 49:143-159

Round PD, Gale GA (2008) Changes in the status of Lophura pheasants in Khao Yai National Park, Thailand: a response to warming climate? Biotropica 40:225-230

Salzmann U, Haywood AM, Lunt DJ, Valdes PJ, Hill DJ (2008) A new global biome reconstruction and data-model comparison for the Middle Pliocene. Global Ecol Biogeogr 17:432-447

Salzmann U, Haywood AM, Lunt DJ (2009) The past is a guide to the future? Comparing Middle Pliocene vegetation with predicted biome distributions for the twenty-first century. Philos Trans R Soc A 367:189-204

SAMD [Southeast Asian Mammal Databank] (2008) Ecological data set and GIS based models: a tool for biodiversity based conservation in Southeast Asia. Instituto di Ecologia Applicata, Rome, Italy. http://www.ieaitaly.org/samd/ (last update June 2008)

Sathiamurthy E, Voris HK (2006) Maps of Holocene sea level transgression and submerged lakes on the Sunda Shelf. Nat Hist J Chulalongkorn University, Supplement 2:1-43. Maps available at http://fmnh.org/research_collections/zoology/zoo_sites/seamaps/

Scholes RJ, Mace GM, Turner W, Geller GN, Jurgens N, Larigauderie A, Muchoney D, Walther BA, Mooney HA (2008) Ecology-toward a global biodiversity observing system. Science 321:1044-1045

Sergio F, Caro T, Brown D, Clucas B, Hunter J, Ketchum J, McHugh K, Hiraldo F (2008) Top predators as conservation tools: ecological rationale, assumptions, and efficacy. Annu Rev Ecol Evol Syst 39:1-19

Sexton JP, McIntyre PJ, Angert AL, Rice KJ (2009) Evolution and ecology of species range limits. Annu Rev Ecol Evol Syst 40:415-436

Sheridan JA (2009) Reproductive variation corresponding to breeding season length in three tropical frog species. J Trop Ecol 25:583-592

Sodhi NS, Brook BW (2006) Southeast Asian biodiversity in crisis. Cambridge University Press, Cambridge

Sodhi NS, Brook BW, Bradshaw CJA (2007) Tropical conservation biology. Blackwell, Oxford

Sodhi NS, Lee TM, Sekercioglu CH, Webb EL, Prawiradilaga DW, Lohman DJ, Pierce NE, Diesmos AC, Rao M, Ehrlich PR (2010) Local people value environmental services provided by forested parks. Biodivers Conserv (this volume). doi:10.1007/s10531-009-9745-9

Sosdian S, Rosenthal Y (2009) Deep-sea temperature and ice volume changes across the PliocenePleistocene climate transitions. Science 325:306-310

Spalding MD, Green EP, Ravilious C (2001) World atlas of coral reefs. University of California Press, Berkeley

Srikwan S, Woodruff DS (2000) Genetic erosion in isolated small mammal populations following rain forest fragmentation. In: Young A, Clarke G (eds) Genetics demography and viability of fragmented populations. Cambridge University Press, Cambridge, pp 149-172

Srikwan S, Jakobsson M, Albrecht A, Dalkilic M (2006) Trust establishment in data sharing: an incentive model for biodiversity information systems. TrustCol 2006:1-8

Sterling EJ, Hurley MM, Minh LD (2006) Vietnam: a natural history. Yale University Press, New Haven

Taylor D (2010) Biomass fires, humans and climate change in Southeast Asia. Biodivers Conserv (this volume) doi:10.1007/s10531-009-9756-6

Tougard C, Montuire S (2006) Pleistocene paleoenvironmental reconstructions and mammalian evolution in South-East Asia: focus on fossil faunas from Thailand. Quat Sci Rev 25:126-141

UNDP (2008) Tonle Sap conservation project. Project Fact Sheet 01/2008 (project 00038552). UNDP Cambodia

van Steenis CGGJ (1950) The delimitation of Malesia and its main plant geographical divisions. Flora Malesiana I(1):1xx-1xxy

Wallace AR (1876) The geographical distribution of animals. Macmillan, London

Wang XM, Sun XJ, Wang PX, Stattegger K (2009) Vegetation on the Sunda Shelf, South China Sea, during the last glacial maximum. Palaeogeogr Palaeoclimatol Palaeoecol 278:88-97

Warner K, Erhart C, de Sherbinin A, Adamo S (2009) In search of shelter: mapping the effects of climate change on human migration and displacement. CARE International, $36 \mathrm{pp}$. http://www.careclimate change.org

Watershed (1999) Man and forest debate. Towards Ecological Recovery and Regional Alliance (TERRA), Bangkok vol 5, pp 1-60. Available at www.terrafer.org 
Watershed (2006) (No title: see papers on transboundary impacts by C Middleton and G Lee, and the Mekong River Commission by $\mathrm{P}$ Hirsch). Towards Ecological Recovery and Regional Alliance (TERRA), Bangkok, vol 12(1), pp 1-60. Available at www.terrafer.org

WBGU (German Advisory Council on Global Change) (2007) The future oceans - warming up, rising high, turning sour. Schubert R et al. (eds) Special Rpt, Berlin. Available at http://www.wbgu.de

Webb CO, Cannon CH, Davies SJ (2008) Ecological organization, biogeography, and the phylogenetic structure of tropical forest tree communities. In: Schnitzer SA, Carson W (eds) Tropical forest community ecology. Wiley-Blackwell, New York, pp 79-97

Webb CO, Slik JWF, Triono T (2010) Biodiversity inventory and informatics in Southeast Asia. Biodivers Conserv (this issue)

Wells DR (1999) The birds of the Thai-Malay peninsula, vol 1. Academic, San Diego, p xix

Western D, Wright RM, Strum SS (1994) Natural connections. Perspectives in community-based conservation. Island Press, Washington

Whitmore TC (ed) (1987) Biogeographical evolution of the Malay archipelago. Oxford University Press, Oxford

Whitmore TC (1998) An introduction to tropical rain forests. Oxford University Press, Oxford

Wikramanayake E, Dinerstein E, Loucks C, Olson D, Morrison J, Lamoreux J, McKnight M, Hedao P (eds) (2002) Terrestrial ecoregions of the Indo-Pacific: a conservation assessment. Island Press, Washington

Wilcove DS, Koh LP (2010) Addressing the threats to biodiversity from oil palm agriculture. Biodivers Conserv. doi:10.1007/s10531-009-9760-X

Willis KJ, Araujo MB, Bennett KD, Figueroa-Rangel B, Froyd CA, Myers N (2007) How can a knowledge of the past help to conserve the future? Biodiversity conservation and the relevance of long-term ecological studies. Philos Trans R Soc B 362:175-186

Woodruff DS (1990) Genetics and demography in the conservation of biodiversity. J Sci Soc Thailand $16: 117-132$

Woodruff DS (1992) Genetics and the conservation of animals in fragmented habitats. In: In Harmony with Nature. Proc intl conf trop biodivers, Malay Nature Soc, Kuala Lumpur, pp 258-272

Woodruff DS (2001a) Declines of biomes and biotas and the future of evolution. Proc Natl Acad Sci USA 98:5471-5476. Available at http://www.pnas.org/cgi/reprint/98/10/5471.pdf

Woodruff DS (2001b) Sustainable agriculture and biodiversity conservation. In: Sustainable agriculture: possibility \& direction. Proc 2nd Asia-Pacific conf sustainable agric, Phitsanulok, Thailand, pp 55-62

Woodruff DS (2003a) Neogene marine transgressions, paleogeography and biogeographic transitions on the Thai-Malay Peninsula. J Biogeogr 30:551-567

Woodruff DS (2003b) The location of the Indochinese-Sundaic biogeographic transition in plants and birds. Nat Hist Bull Siam Soc 51:97-108

Woodruff DS (2003c) Non-invasive genotyping and field studies of free-ranging non-human primates. In: Chapais B, Berman C (eds) Kinship and behavior in primates. Oxford University Press, Oxford, pp 46-68

Woodruff DS (2006) Genetics and the future of biodiversity. Keynote talk: Proc. 9th Annu Thai biodiversity research \& training progr, Bangkok, pp 20-29

Woodruff DS (2008) International impacts of damming the Mekong River. In: DiFrancesco K, Woodruff K (eds) Global perspectives on large dams. Evaluating the state of large dam construction and decommissioning across the world. Report No 13, Yale School of Forestry \& Environmental Studies, New Haven, pp 85-89

Woodruff DS, Turner LM (2009) The Indochinese-Sundaic zoogeographic transition: a description of terrestrial mammal species distributions. J Biogeogr 36:803-821

Woodruff DS, Woodruff KA (2008) Paleogeography, global sea level changes, and the future coastline of Thailand. Nat Hist Bull Siam Soc 56:1-24

World Bank (2009) World development report 2010: development and climate change. The World Bank, Washington DC (www.worldbank.org/wdr2010). See: Focus B. Biodiversity and ecosystem services in a changing climate, pp 124-131

World Wildlife Fund (2009) Heart of Borneo. http://www.wwf.or.id/en/about_wwf/whatwedo/hob/abouthob/ Wright SJ, Muller-Landau HC, Schipper J (2009) The future of tropical species on a warmer planet. Conserv Biol 23:1418-1426

Ziegler AD, Bruun TB, Guardiola-Claramonte M, Giambelluca TW, Lawrence D, Lam NT (2009) Environmental consequences of the demise in swidden cultivation in montane mainland Southeast Asia: hydrology and geomorphology. Human Ecol 37:361-373 